\title{
RETROSPECTIVE ANALYSIS OF BORDERLINE OVARIAN TUMORS: OUTCOMES AT A SINGLE CENTER
}

\author{
Ercan Yilmaz ${ }^{1}$, Nurhan Sahin ${ }^{2}$, Isil Kolelii ${ }^{1}$, Rauf Melekoglu ${ }^{1}$, Emrullah Tanrikut ${ }^{3}$, \\ Simge Faydali ${ }^{1}$, Abdullah Karaer ${ }^{1}$ and Ebru Inci Coskun ${ }^{1}$
}

${ }^{1}$ Inonu University Turgut Ozal Medical Centre, Obstetrics and Gynecology Department, Malatya, Turkey;

${ }^{2}$ Inonu University Turgut Ozal Medical Centre, Pathology Department, Malatya, Turkey;

${ }^{3}$ Gozde Academy, Malatya, Turkey

\begin{abstract}
SUMMARY - We wanted to discuss our experiences in the approach to borderline ovarian tumors, which constitute a group different from epithelial ovarian tumors with respect to their biological structure in line with retrospective information gathered from our cases. A total of 25 patients operated on for the indication of adnexal masses diagnosed as borderline ovarian tumors based on frozen section results were included in our study. Patient age, tumor diameter, tumor markers and surgeries performed were discussed in the light of the literature. Statistical analyses were performed using the SPSS software. The patient mean age was $43.84 \pm 11.34$ years. The mass was localized in the right $(\mathrm{n}=13)$, left $(\mathrm{n}=11)$ or both $(\mathrm{n}=1)$ adnexal regions. The mean tumor diameter was $12.9 \pm 5.84 \mathrm{~cm}$. Histopathologic examination established the diagnosis of serous borderline ( $\mathrm{n}=14$ patients) and mucinous borderline $(n=11)$ ovarian tumors. Although the results of our study are consistent with current literature data, a greater number of current studies should be performed on borderline ovarian tumors, which are defined as a class of tumors different from epithelial ovarian tumors.
\end{abstract}

Key words: Ovarian neoplasms - diagnosis; Ovarian neoplasms - classification; Cystadenocarcinoma, serous - diagnosis; Carcinoma, ovarian epithelial - diagnosis

\section{Introduction}

The term borderline ovarian tumor (BOT), which accounts for $10 \%-20 \%$ of all epithelial ovarian tumors, was first used by Taylor et al. in 1929 for a group of completely different ovarian masses between benign and manifest malignant tumors as for its histologic and behavioral characteristics. During subsequent years, this definition was altered somewhat; in 1973, the International Federation of Gynecology and $\mathrm{Ob}-$ stetrics (FIGO) introduced the term "tumor with low malignant potential" into the literature; and finally the

Correspondence to: Ercan Yilmaz, Inonu University Turgut Ozal Medical Centre, Obstetrics and Gynecology Department, Malatya, Turkey

E-mail: ercanyilmazgyn@yahoo.com

Received February 6, 2017, accepted November 30, 2018
World Health Organization defined these mass lesions as "borderline ovarian tumor (BOT)", which is still used today ${ }^{1}$.

Histologic diagnosis of BOT is based on the criteria described by Hart and Norris and detailed by Scully as follows: epithelial cellular proliferation (stratification of the epithelial lining of the papillae, multi-layering of the epithelium, mitotic activity and nuclear atypia) without stromal invasion. Obvious stromal invasion is the principal diagnostic criterion for $\mathrm{BOT}^{2}$. Although in recent years the definition of microinvasive BOT has been revived, it indicates a special subclassification. It is defined as the presence of stromal invasion of one or more than one foci smaller than 3 $\mathrm{mm}$ or $10 \mathrm{~mm}^{2(3)}$.

An important part of BOT has mucinous or serous histologic types; however, $4 \%-5 \%$ of these are clear 
cell, endometrioid, mixed, transitional or Brenner type of tumors. Serous and mucinous borderline types comprise $43 \%-53 \%$ and $42 \%-52 \%$ of all BOTs, respective$1 \mathrm{y}^{4}$. Approximately $30 \%$ of serous borderline tumors are bilateral, and frequently extraovarian invasion in the form of peritoneal implants is detected. The majority of peritoneal implants are noninvasive, and invasive peritoneal implants are detected in nearly $30 \%-35 \%$ of cases. Although invasive implants may demonstrate disease progression, in most of the cases, surgical resection suffices. However, the incidence of bilaterality and extraovarian spread is lower in mucinous borderline tumors ${ }^{5}$.

Standard surgical treatment in patients diagnosed with serous BOT on the basis of intraoperative frozen section examination consists of hysterectomy with bilateral salpingo-oophorectomy (in young fertile $\mathrm{pa}^{-}$ tients, unilateral salpingo-oophorectomy and contralateral ovarian biopsy to assess the opposite ovary), multiple peritoneal biopsies, and sampling from peritoneal irrigation fluid for cytologic evaluation. In mucinous tumors, additional appendectomy should be performed. Although lymphadenectomy is not the currently recommended surgical treatment for BOT, it has been shown that even in cases with lymph node involvement, survival and recurrence rates have not changed $^{6}$. Nowadays, studies demonstrating beneficial effects of adjuvant treatments such as chemotherapy and radiotherapy in patients with advanced stage BOT or invasive peritoneal implants are lacking. As it is known, patients with advanced stage BOT respond well to cisplatin-based adjuvant chemotherapeutic regimens, however, there is no favorable effect on longterm survival ${ }^{7}$.

We analyzed the characteristic features of the patients operated in our department with the diagnosis of BOT in the light of the information summarized above and literature data. We believe that the data retrieved from our study would shed more light on diverse opinions on the issue, especially concerning treatment of these patients.

\section{Patients and Methods}

\section{Patient selection}

The study included 25 patients operated for adnexal mass diagnosed as BOTs based on frozen section examination between 2011 and 2016 at Department of Gynecology and Obstetrics, Inönü University, Faculty of Medicine, Turgut Özal Medical Center. Preoperative levels of cancer antigen-125 (CA 125), carcinoembryonic antigen (CEA), cancer antigen 19-9 (CA 19-9) and cancer antigen 15-3 (CA 15-3) were measured in the patients. Location of the adnexal mass (right or left ovary), diameter, and histologic type of the tumor, analytical results of peritoneal irrigation fluid, the surgical procedure performed, results of peritoneal biopsy and number of pelvic/paraaortic lymph nodes were recorded. All patients were staged based on the FIGO classification system as revised in 2009. The mean patient follow-up period was $48 \pm 9.02$ months.

\section{Histopathologic evaluation}

Serous borderline tumors display a hierarchical, branching architecture lined by cuboidal to columnar epithelium with minimal cytologic atypia. Many tumors had a variable number of polygonal and hobnail cells with eosinophilic cytoplasm containing moderately enlarged, hyperchromatic nuclei and sometimes nucleoli. Mucinous borderline tumors were lined by gastrointestinal-type epithelium in the form of gastric pyloric-type epithelium, goblet cells. The epithelium exhibited varying degrees of stratification, tufting and villous or slender filiform papillae. The cells showed mild to moderate nuclear enlargement, hyperchromasia and sometimes pseudostratification, but high-grade nuclear features were not seen (Figs. 1 and 2).

\section{Statistical analysis}

Statistical analyses were performed using SPSS software (SPSS for Mac Inc., Chicago, IL, US). We computed descriptive statistics (mean and range).

\section{Results}

A total of 25 patients (mean age $43.84 \pm 11.34$ years) with the diagnosis of BOT were included in the study. The youngest and oldest patients were aged 24 and 68 years, respectively. All patients were diagnosed intraoperatively as BOT based on frozen section examinations, and subsequently the diagnosis was confirmed by examination of paraffin blocks. The examination of frozen sections established the diagnosis of serous or mucinous BOT with $100 \%$ accuracy. Intraoperative 


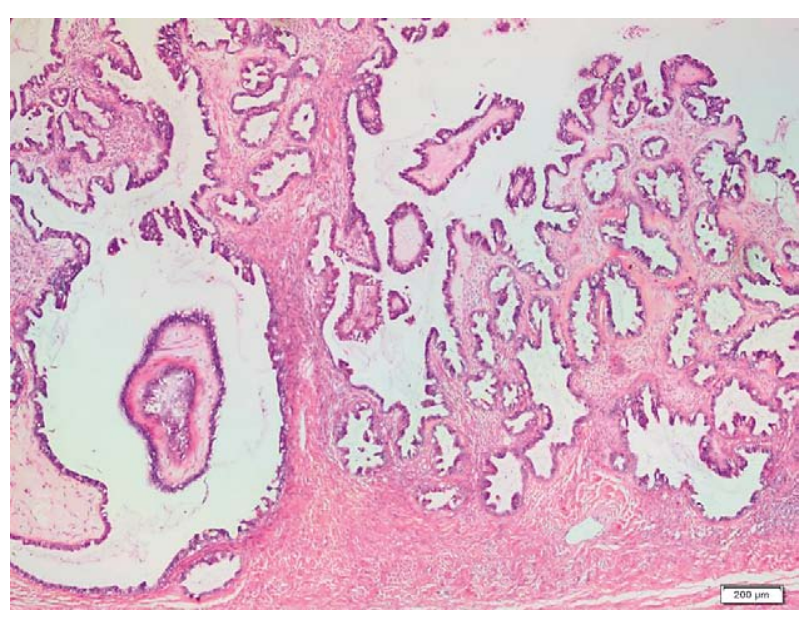

Fig. 1. Histologic appearance of serous borderline ovarian tumor (HEx40).

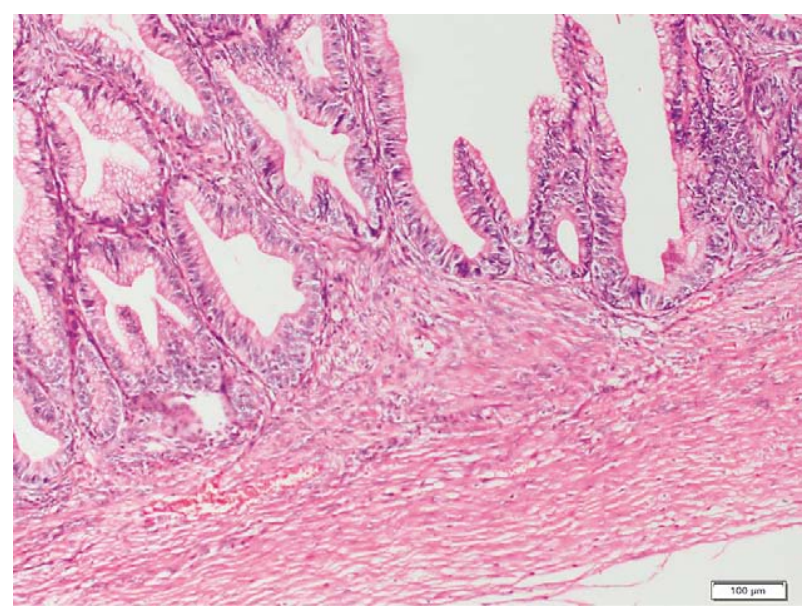

Fig. 2. Histologic appearance of mucinous borderline ovarian tumor (HEx40).

exploration revealed mass lesions in the right $(n=13)$, left $(n=11)$, and both $(n=1)$ adnexal regions. The mean tumor diameter was $12.9 \pm 5.84 \mathrm{~cm}(\min 5 \mathrm{~cm}$ and $\max$ $26 \mathrm{~cm}$ ). Based on histopathologic examination, the diagnosis of serous and mucinous BOT was made in 14 and 11 patients, respectively.

During the preoperative period, the mean levels of CA 125, CEA, CA19-9 and CA 15-3 in all study patients were $63.19 \pm 93.8 \mathrm{U} / \mathrm{mL}$ (range $3.09-394 \mathrm{U} /$ $\mathrm{mL}$ ), $31.29 \pm 76.63 \mathrm{U} / \mathrm{mL}, 20.83 \pm 11.24 \mathrm{U} / \mathrm{mL}$ (range $6.40-48.60 \mathrm{U} / \mathrm{mL}$ ) and $2.32 \pm 2.09 \mathrm{ng} / \mathrm{mL}$ (range $0.50-$ $10.8 \mathrm{ng} / \mathrm{mL}$ ), respectively. The highest and lowest CA $19-9$ values measured in our patients were $0.60 \mathrm{U} / \mathrm{mL}$ and $382 \mathrm{U} / \mathrm{mL}$, respectively.
Table 1. Characteristics of patients diagnosed with serous-mucinous borderline ovarian tumors

\begin{tabular}{|c|l|l|l|l|}
\hline $\begin{array}{l}\text { Patient } \\
\text { No. }\end{array}$ & $\begin{array}{l}\text { Age } \\
\text { (years) }\end{array}$ & $\begin{array}{l}\text { Tumor } \\
\text { diameter } \\
(\mathrm{cm})\end{array}$ & $\begin{array}{l}\text { Tumor } \\
\text { localization }\end{array}$ & $\begin{array}{l}\text { Histologic } \\
\text { type }\end{array}$ \\
\hline 1 & 50 & 12 & Right & Serous \\
2 & 53 & 16 & Right & Serous \\
3 & 52 & 24 & Left & Serous \\
4 & 41 & 8 & Left & Serous \\
5 & 62 & 6 & Left & Mucinous \\
6 & 43 & 14 & Left & Mucinous \\
7 & 50 & 11 & Left & Serous \\
8 & 34 & 12 & Right & Mucinous \\
9 & 48 & 8 & Right & Serous \\
10 & 52 & 24 & Right & Serous \\
11 & 25 & 26 & Right & Mucinous \\
12 & 46 & 12 & Right & Serous \\
13 & 45 & 10 & Right & Serous \\
14 & 34 & 8 & Right & Mucinous \\
15 & 42 & 15 & Left & Serous \\
16 & 48 & 18 & Left & Mucinous \\
17 & 46 & 21 & Left & Serous \\
18 & 51 & 6 & Bilateral & Serous \\
19 & 30 & 5 & Left & Mucinous \\
20 & 68 & 8 & Right & Mucinous \\
21 & 28 & 10 & Left & Serous \\
22 & 27 & 10 & Left & Mucinous \\
23 & 54 & 12 & Left & Mucinous \\
24 & 43 & 16 & Right & Serous \\
25 & 24 & 12 & Left & Mucinous \\
\hline
\end{tabular}

Although laparoscopy and laparotomy as options were explained to the patients, laparotomic surgery was carried out according to the patient's preference. In all patients undergoing surgery, peritoneal irrigation fluid was obtained as part of the surgical procedure. Cytologic examination of all samples obtained was reported as having benign characteristics. All patients with the diagnosis of mucinous BOT underwent appendectomy, and malignancy was not observed in any specimen. Multiple peritoneal biopsies were obtained from all patients. Pelvic parietal peritoneum, peritoneum of the Douglas pouch, mesentery of rectum and sigmoid colon, and abdominal parietal peritoneum were the preferred anatomical regions for sampling. Invasive or noninvasive metastatic implants were not 
Table 2. Preoperative tumor markers in patients and surgical treatments applied

\begin{tabular}{|c|c|c|c|c|c|c|c|}
\hline $\begin{array}{l}\text { Patient } \\
\text { No. }\end{array}$ & $\begin{array}{l}\mathrm{CA} 125 \\
(\mathrm{U} / \mathrm{mL})\end{array}$ & $\begin{array}{l}\text { CEA } \\
(\mathrm{ng} / \mathrm{mL})\end{array}$ & $\begin{array}{l}\text { CA19-9 } \\
(\mathrm{U} / \mathrm{mL})\end{array}$ & $\begin{array}{l}\text { CA } 15-3 \\
(\mathrm{U} / \mathrm{mL})\end{array}$ & Surgical treatments performed & $\begin{array}{l}\text { Pelvic } \\
\text { lymph } \\
\text { node }\end{array}$ & $\begin{array}{l}\text { Paraaortic } \\
\text { lymph } \\
\text { node }\end{array}$ \\
\hline 1 & 147 & 2.34 & 382 & 20.7 & $\begin{array}{l}\text { TAH + BSO + omentectomy + PPLND } \\
+ \text { multiple peritoneal biopsies }\end{array}$ & 24 & 26 \\
\hline 2 & 3.09 & 4.38 & 27.6 & 20.1 & $\begin{array}{l}\text { TAH + BSO + omentectomy + PPLND } \\
+ \text { multiple peritoneal biopsies }\end{array}$ & 17 & 22 \\
\hline 3 & 12.6 & 10.8 & 25.2 & 12.8 & $\begin{array}{l}\text { USO + contralateral ovarian biopsy } \\
+ \text { multiple peritoneal biopsies }\end{array}$ & & \\
\hline 4 & 7.86 & 3.24 & 88.8 & 31.4 & $\begin{array}{l}\text { TAH + BSO + omentectomy + PPLND } \\
+ \text { multiple peritoneal biopsies }\end{array}$ & 24 & 9 \\
\hline 5 & 10.6 & 1.4 & 31.4 & 48.6 & $\begin{array}{l}\mathrm{TAH}+\mathrm{BSO}+\text { multiple peritoneal biopsies } \\
+ \text { appendectomy }\end{array}$ & & \\
\hline 6 & 10.2 & 1.24 & 2.5 & 28.5 & $\begin{array}{l}\text { USO + contralateral ovarian biopsy }+ \\
\text { multiple peritoneal biopsies }+ \text { appendectomy }\end{array}$ & & \\
\hline 7 & 12.2 & 1.22 & 9.7 & 8.2 & TAH + BSO + multiple peritoneal biopsies & & \\
\hline 8 & 11.4 & 0.85 & 0.8 & 10.7 & $\begin{array}{l}\text { USO + contralateral ovarian biopsy }+ \\
\text { multiple peritoneal biopsies }+ \text { appendectomy }\end{array}$ & & \\
\hline 9 & 51.1 & 3.17 & 0.8 & 10.9 & TAH + BSO + multiple peritoneal biopsies & & \\
\hline 10 & 10.8 & 1.85 & 1.2 & 6.4 & TAH + BSO + multiple peritoneal biopsies & & \\
\hline 11 & 183.1 & 1.44 & 0.6 & 31.4 & $\begin{array}{l}\text { USO + contralateral ovarian biopsy }+ \\
\text { multiple peritoneal biopsies }+ \text { appendectomy }\end{array}$ & & \\
\hline 12 & 6.86 & 0.74 & 12.1 & 7.82 & $\begin{array}{l}\text { TAH + BSO + omentectomy + PPLND } \\
+ \text { multiple peritoneal biopsies }\end{array}$ & 11 & 16 \\
\hline 13 & 178.7 & 1.5 & 1.2 & 30.5 & $\mathrm{TAH}+\mathrm{BSO}+$ multiple peritoneal biopsies & & \\
\hline 14 & 20.0 & 1.74 & 2.5 & 10.4 & $\begin{array}{l}\text { USO + contralateral ovarian biopsy + } \\
\text { multiple peritoneal biopsies }+ \text { appendectomy }\end{array}$ & & \\
\hline 15 & 11.6 & 1.62 & 9.53 & 11.5 & $\begin{array}{l}\text { USO + contralateral ovarian biopsy } \\
+ \text { multiple peritoneal biopsies }\end{array}$ & & \\
\hline 16 & 8.35 & 0.78 & 2.5 & 35.5 & $\begin{array}{l}\mathrm{TAH}+\mathrm{BSO}+\text { multiple peritoneal biopsies } \\
+ \text { appendectomy }\end{array}$ & & \\
\hline 17 & 23.1 & 1.21 & 13.8 & 20.9 & $\begin{array}{l}\text { USO + contralateral ovarian biopsy } \\
+ \text { multiple peritoneal biopsies }\end{array}$ & & \\
\hline 18 & 146 & 1.07 & 7.04 & 25.9 & $\mathrm{TAH}+\mathrm{BSO}+$ multiple peritoneal biopsies & & \\
\hline 19 & 16.9 & 2.04 & 47.4 & 8.8 & $\begin{array}{l}\text { USO + contralateral ovarian biopsy }+ \\
\text { multiple peritoneal biopsies + appendectomy }\end{array}$ & & \\
\hline 20 & 24.1 & 3.68 & 2.5 & 32.2 & $\begin{array}{l}\text { TAH + BSO + multiple peritoneal biopsies } \\
+ \text { appendectomy }\end{array}$ & & \\
\hline 21 & 194 & 1.74 & 75.8 & 14.6 & $\begin{array}{l}\text { USO + contralateral ovarian biopsy } \\
+ \text { multiple peritoneal biopsies }\end{array}$ & & \\
\hline 22 & 62.5 & 0.5 & 2.5 & 18.6 & $\begin{array}{l}\text { USO + contralateral ovarian biopsy }+ \\
\text { multiple peritoneal biopsies + appendectomy }\end{array}$ & & \\
\hline 23 & 12.5 & 4.54 & 2.5 & 25.8 & $\begin{array}{l}\mathrm{TAH}+\mathrm{BSO}+\text { multiple peritoneal biopsies } \\
+ \text { appendectomy }\end{array}$ & & \\
\hline 24 & 394 & 3.32 & 23.2 & 36.2 & $\begin{array}{l}\text { TAH + BSO + omentectomy + PPLND } \\
+ \text { multiple peritoneal biopsies }\end{array}$ & 17 & 26 \\
\hline 25 & 21.4 & 1.66 & 9.08 & 12.4 & $\begin{array}{l}\mathrm{USO}+\text { contralateral ovarian biopsy }+ \\
\text { multiple peritoneal biopsies }+ \text { appendectomy }\end{array}$ & & \\
\hline
\end{tabular}

CA $125=$ cancer antigen 125; Ca 19-9 = cancer antigen 19-9; CA 15-3 = cancer antigen 15-3; CEA = carcinoembryonic antigen; TAH = total abdominal hysterectomy; $\mathrm{BSO}=$ bilateral salpingo-oophorectomy; PPLND = pelvic-paraaortic lymphadenectomy; USO = unilateral salpingo-oophorectomy 
detected in peritoneal biopsy specimens. Patients in their reproductive age underwent fertility-preserving surgeries. Five fertile patients underwent total abdominal hysterectomy together with bilateral salpingo-oophorectomy, pelvic and paraaortic lymphadenectomy, and omentectomy. Nine patients underwent total abdominal hysterectomy and omentectomy. Eleven patients underwent unilateral salpingo-oophorectomy and contralateral ovarian biopsy procedures.

Lymphadenectomy procedure was performed systematically via dissection over obturator nerve in pelvis, bilaterally up to the renal vein in the paraaortic region. The mean number of pelvic and paraaortic lymph nodes was $18.6 \pm 5.50$ (range 11-24) and 19.8 \pm 7.29 (range 9-26), respectively. Lymph nodes in the pelvic and paraaortic regions were not pathologic. All patients were staged based on the FIGO classification system as revised in 2009, and they were evaluated as stage IA patients. In order to compare cytoreductive and conservative surgery in the treatment of BOTs, systematic lymphadenectomy was performed in five patients. Adjuvant chemotherapy and/or adjuvant surgery was not required. During two years of follow-up, there was no disease recurrence. Patient characteristics are summarized in Tables 1 and 2.

\section{Discussion}

In BOTs, atypical epithelial proliferation without stromal invasion is detected; these tumors are diagnosed based on histopathologic criteria and account for $10 \%-15 \%$ of all epithelial ovarian tumors. Because of their atypical structures, they are classified in a group other than epithelial ovarian tumors ${ }^{8}$. In essence, BOTs differ greatly from epithelial ovarian tumors, at least with respect to their age at onset and prognosis. When compared with ovarian cancers, BOTs are seen at an earlier age. Besides, even in cases with detected peritoneal invasion, the mean survival times are longer relative to epithelial ovarian tumors. The 5- and 10-year survival rates for BOT stage I, II and III were $99 \%, 97 \%$ and $98 \%$ vs. $90 \%, 96 \%$ and $88 \%$, respectively ${ }^{5}$. Still, the great majority of these are diagnosed at an early stage. Contrary to epithelial ovarian tumors, most of them are detected when they are contained in a single ovary at a noninvasive stage. In a meta-analysis exploring data on 6362 patients diagnosed with BOT, $78.9 \%$ of the cases had been diag- nosed as FIGO stage $\mathrm{I}^{4}$. In accordance with literature findings, the patient mean age in our study was $43.84 \pm 11.34$ years. The youngest patient was aged 24 years, while seven patients were aged less than 40 . All our study patients were evaluated as stage IA, and no disease recurrence was detected in all patients within two years.

Histologically important part of the cases with BOT are mucinous or serous tumors, however, clear cell, endometrioid, mixed, transitional or Brenner type tumors are detected in $4 \%-5 \%$ of cases. Serous borderline and mucinous histologic subtypes comprise 43\%$53 \%$ and $42 \%-52 \%$ of all BOTs, respectively 5 . In our study, serous and mucinous BOTs were diagnosed in 14 and 11 patients, respectively. BOTs were located in the right $(n=13)$, left $(n=11)$ or both $(n=1)$ adnexal regions.

Preoperative evaluation of BOTs is still a controversial issue. Relevant data cannot be found especially on serum tumor markers. In a study performed by Van Calster et al., the authors demonstrated that since serum CA125 levels increase in BOTs and early-stage epithelial ovarian tumors, the use of this parameter in preoperative evaluation would not be appropriate ${ }^{9}$. In another study, increased serum CA125 levels were recorded in $40 \%$ of the patients diagnosed as stage 1 BOT and $83 \%$ of those with advanced-stage BOT $^{10}$. However, studies on other serum tumor markers including CA19-9, CA15-3 and CEA are not available ${ }^{11}$. In our study, we detected higher serum CA-125 levels in eight patients (upper limit of normal $=35 \mathrm{U} / \mathrm{mL}$ )

Serous BOTs especially tend to spread through peritoneal metastases rather than lymphatic route. These peritoneal metastases demonstrate noninvasive and invasive characteristics. Noninvasive peritoneal implants constitute $85 \%$ of peritoneal metastases, however, evidence for stromal invasion cannot be detected in biopsy specimens ${ }^{12}$. Noninvasive peritoneal implants histopathologically demonstrate epithelial or desmoplastic features. However, prognosis is similar in both types. Still, as demonstrated in various studies, since desmoplastic noninvasive implants have a more complex structure, they have a higher potential for stromal microinvasion ${ }^{13}$. The mean survival times of patients with peritoneal implants are adversely affected. Mortality rates of $4.7 \%$ and $34 \%$ have been reported for patients with invasive and noninvasive peritoneal implants, respectively ${ }^{14}$. The presence of micro- 
papillary structure is another aspect of serous BOTs. The presence of this structure affects prognosis adversely, however, the main problem is increase in the rates of invasive recurrence in patients with micropapillary structure ${ }^{15}$. In their study, Shih et al. demonstrated that during 4 years of follow-up, the rates of invasive recurrences were higher and naturally disease-free survival rates significantly lower in patients with micropapillary structure when compared with those without micropapillary structure $(75.9 \% \text { vs. } 94.3 \%)^{16}$. The presence of stromal microinvasion in serous borderline tumors has become a debatable issue. Microinvasion has been defined as the presence of invasion of less than $3 \mathrm{~mm}$ or $10 \mathrm{~mm}^{2}$ in one or more than one focus ${ }^{17}$. Although it is still a debatable issue whether the risk of invasive recurrence increases in cases with microinvasion, literature surveys indicate that microinvasive structure is recognized as a prognostic factor for serous $\mathrm{BOT}^{12}$. In our study, microinvasive and micropapillary structure was not detected in 14 patients diagnosed as serous BOT. Besides, invasive or noninvasive formations were not observed in peritoneal biopsies. Intraepithelial carcinoma, which is associated with higher recurrence rates and used to describe mucinous BOTs, is currently considered a debatable concept by many authors. Histopathologically, a consensus has been reached concerning its relationship with severe epithelial dysplasia that does not penetrate beyond basal membrane. Indeed, in a case series analyzed, the risk of recurrence in mucinous borderline tumors containing foci of intraepithelial carcinoma was unexpectedly high for this group of tumors ${ }^{18}$. The term of stromal microinvasion defined for serous borderline tumors based on diagnostic criteria also holds true for mucinous BOTs. However, in a large-scale case series, the authors demonstrated that the presence of microinvasion in mucinous tumors was not associated with the frequency of invasive recurrences and prognosis ${ }^{19}$. In our study, intraepithelial carcinoma and stromal invasion were not detected in 11 patients diagnosed with mucinous BOT.

Surgical alternative defined and accepted for the treatment of BOTs should be unilateral/bilateral salpingo-oophorectomy and hysterectomy if necessary. Surgical staging is realized through peritoneal sampling or lymph node dissection ${ }^{12}$. We did not take a standard criterion for lymphadenectomy; these patients underwent systematic lymphadenectomy. Since these tumors are observed at an early age, conservative treatment alternative (unilateral ovary and/or uterus sparing surgeries) can be applied in patients of fertile age. It should not be forgotten that fertility sparing surgery is an appropriate preference for patients in whom peritoneal implant is detected. In a meta-analysis of outcomes in nearly 2000 patients, higher recurrence rates were demonstrated for patients having undergone bilateral salpingo-oophorectomy when compared to those with hysterectomy with bilateral salpingo-oophorectomy. However, it has also been reported that this condition does not imply an adverse effect on survival rates, and a redo-surgical excision could be performed successfully ${ }^{20}$. In another study, recurrence rates were $12 \%-58 \%$ in patients diagnosed with BOT and having undergone conservative surgery (cystectomy), whereas in the group having undergone extensive surgery (bilateral salpingo-oophorectomy) recurrence rates ranged between 0 and $20 \% 1$.

Lymph node involvement was reported in $25 \%$ of patients with advanced stage BOTs (FIGO stages III and IV). Molecular and histologic data obtained from cases with lymph node metastases support the presence of a synchronized ovarian tumor ${ }^{21}$. Many studies have demonstrated that lymph node involvement in patients diagnosed with BOT did not exert an adverse effect on survival times ${ }^{12}$. In a similar study, KanatPektas et al. stated that lymphadenectomy could not be performed as a surgical treatment in cases diagnosed with BOT considering the lack of any significant difference in survival times between the groups having and having not undergone lymphadenectomy ${ }^{22}$. In our study, we used fertility-sparing surgeries (unilateral salpingo-oophorectomy, contralateral ovarian biopsy, and multiple peritoneal sampling) in 11 patients. After long-term follow-up, we did not detect any recurrences in our patients. In patients with preoperatively increased serum tumor marker levels and large $(\geq 15 \mathrm{~cm})$ ovarian tumors, where we palpated retroperitoneal lymph nodes during intraoperative period, we systematically applied lymphadenectomy procedures. We used this surgical procedure in five patients, but we could not detect any metastatic lymph node.

Since a significant proportion of patients diagnosed with BOT are young women and have a desire to give birth, laparoscopic surgical intervention should be considered. However, when the risks of cyst rupture, intraperitoneal dissemination of tumor cells and tu- 
mor metastases to trocar incision were considered, laparotomy was thought to be more advantageous ${ }^{12}$. Studies performed have shown that the risks of cyst rupture and recurrence were greater when compared with laparotomic approach ${ }^{23}$. It should be noted that eight cases with trocar metastases detected during postoperative period are described in the literature ${ }^{24}$. We applied laparotomic surgery in all of our study patients.

In conclusion, BOTs have completely different biological characteristics from epithelial ovarian tumors with respect to tumor behavior and prognosis. For these tumors, which are mostly detected in young women at an early stage, fertility-sparing surgeries can be applied. The pathogenesis and treatment of these tumors are still debatable issues, and a greater number of studies should be available in the literature. Within this context, we believe that our study would shed some new light on these controversial issues.

\section{References}

1. Trope GC, Kaern J, Davidson B. Borderline ovarian tumors. Best Pract Res. 2012;26:325-36. DOI: $10.1016 /$ j.bpobgyn.2011.12.006

2. Morris CR, Liu L, Rodriguez AO, Cress DR, Snipes K. Epidemiologic features of borderline ovarian tumors in California: a population-based study. Cancer Causes Control. 2013;24: 665-74. DOI: 10.1007/s10552-013-0145-9

3. Seidman JD, Soslow RA, Vang R, et al. Borderline ovarian tumors: diverse contemporary viewpoints on terminology and diagnostic criteria with illustrative images. Hum Pathol. 2004; 35:918-33. DOI: 10.1016/j.humpath.2004.03.004

4. Trillsch F, Mahner S, Ruetzel J, et al. Clinical management of borderline ovarian tumors. Expert Rev Anticancer Ther. 2010; 10:1115-24. DOI: $10.1586 /$ era. 10.90

5. Rasmussen CB, Jensen A, Albieri V, Andersen KK, Kjaer SK. Increased risk of borderline ovarian tumors in women with a history of pelvic inflammatory disease: a nationwide population-based cohort study. Gynecol Oncol. 2016;143:346-51. DOI: 10.1016/j.ygyno.2016.08.318

6. Solmaz Hasdemir P, Guvenal T. Borderline ovarian tumors: a contemporary review of clinicopathological characteristics, diagnostic methods and therapeutic options. JBUON. 2016;21: 780-6.

7. Tropé C, Davidson B, Paulsen T, Abeler VM, Kaern J. Diagnosis and treatment of borderline ovarian neoplasms: "the state of the art”. Eur J Gynaecol Oncol. 2009;30(5):471-82.

8. Shim SH, Kim SN, Phill SJ, Dong M, Kim JE, Lee SJ. Impact of surgical staging on prognosis in patients with borderline ovarian tumors: a meta-analysis. Eur J Cancer. 2016;54:84-95. DOI: 10.1016/j.ejca.2015.11.005
9. Van Calster B, Timmerman D, Bourne T, et al. Discrimination between benign and malignant adnexal masses by specialist ultrasound examination versus serum CA-125. J Natl Cancer Inst. 2007;99:1706-14. DOI: 10.1093/jnci/djm199

10. Fauvet R, Boccara J, Dufournet C, Poncelet C, Darai E. Laparoscopic management of borderline ovarian tumors: results of a French multicenter study. Ann Oncol. 2005;16:403-10. DOI: 10.1093/annonc/mdi083

11. Gungor T, Cetinkaya N, Yalcin H, et al. Retrospective evaluation of borderline ovarian tumors: single center experience of 183 cases. Arch Gynecol Obstet. 2015;291:123-30. DOI: 10.1007/s00404-014-3381-7

12. Morice P, Uzan C, Fauvet R, Gouy S, Duvillard P, Darai E. Borderline ovarian tumour: pathological diagnostic dilemma and risk factors for invasive or lethal recurrence. Lancet Oncol. 2012;13:103-15. DOI: 10.1016/S1470-2045(11)70288-1

13. Hart WR. Borderline epithelial tumors of the ovary. Mod Pathol. 2005;18:33-55. DOI: 10.1038/modpathol.3800307

14. Seidman JD, Kurman RJ. Ovarian serous borderline tumours: a critical review on the literature with emphasis on prognostic factors. Hum Pathol. 2000;31:529-57.

DOI: $10.1053 /$ hp. 2000.8048

15. Deavers MT, Gershenson DM, Tortolero-Luna G, Malpica A, Lu KH, Silva E. Micropapillary and cribriform patterns in ovarian serous tumors of low malignant potential: a study of 99 advanced stage cases. Am J Surg Pathol. 2002;26:1129-41. DOI: 10.1097/00000478-200209000-00003

16. Shih KK, Zhou Q,Huh J. Risk factor for recurrence of ovarian borderline tumors. Gynecol Oncol. 2011;120:480-4. DOI: 10.1016/j.ygyno.2010.11.016

17. Avril S, Hahn E, Specht K, et al. Histopathologic features of ovarian borderline tumors are not predictive of clinical outcome. Gynecol Oncol. 2012;127:516-24. DOI: 10.1016/j.ygyno.2012.08.027

18. Koskas M, Uzan C, Gouy S, et al. Prognostic factors of a large retrospective series of mucinous borderline tumors of the ovary (excluding peritoneal pseudomyxoma). Ann Surg Oncol. 2011; 18(1):40-8. DOI: $10.1245 / \mathrm{s} 10434-010-1293-8$

19. Khunamornpong S, Settakorn J, Sukpan K, Suprasert P, Siriaunkgul S. Mucinous tumor of low malignant potential ("borderline" or "atypical proliferative" tumor) of the ovary: a study of 171 cases with the assessment of intraepithelial carcinoma and microinvasion. Int J Gynecol Pathol. 2011;30(3): 218-30. DOI: 10.1097/PGP.0b013e3181fcf01a

20. Kane A, Uzan C, Rey A, et al. Prognostic factors in patients with ovarian serous low malignant potential (borderline) tumors with peritoneal implants. Oncologist. 2009;14:591-600. DOI: 10.1634/theoncologist.2008-0263

21. McKenney JK, Balzer BL, Longacre TA. Patterns of stromal invasion in ovarian serous tumors of low malignant potential (borderline tumors): a reevaluation of the concept of stromal microinvasion. Am J Surg Pathol. 2006;30:1209-21. DOI: 10.1097/01.pas.0000213299.11649.fa 
22. Kanat-Pektas M, Ozat M, Gungor T, Sahin I, Yalcin H, Ozdal B. Prognostic factors in patients with ovarian serous low malignant potential (borderline) tumors with peritoneal implants. Arch Gynecol Obstet. 2011;283(4):879-84. DOI: 10.1007/ s00404-010-1539-5

23. Poncelet C, Fauvet R, Boccara J, Daraï E. Recurrence after cystectomy for borderline ovarian tumors: results of a French multicenter study. Ann Surg Oncol. 2006;13:565-71. DOI: 10.1245/ASO.2006.12.024

24. Morice P, Camatte C, Larregain-Fournier D, Thoury A, Duvillard P, Castaigne D. Port-site implantation after laparoscopic treatment of borderline ovarian tumors. Obstet Gynecol. 2004;104:1167-70.

DOI: 10.1097/01.AOG.0000124988.46203.f2

Sažetak

\title{
RETROSPEKTIVNA ANALIZA GRANIČNIH TUMORA JAJNIKA: ISHODI U JEDNOM CENTRU
}

\author{
E. Yilmaz, N. Sabin, I. Koleli, R. Melekoglu, E. Tanrikut, S. Faydali, A. Karaer i E. Inci Coskun
}

Želja nam je opisati naša iskustva u pristupu graničnim tumorima jajnika kao skupini tumora koji se razlikuju od epitelnih tumora jajnika prema biološkoj strukturi, sukladno retrospektivnim podacima prikupljenim iz naših slučajeva. U istraživanje je bilo uključeno 25 bolesnica operiranih pod indikacijom adneksnih tvorevina dijagnosticiranih kao granični tumori jajnika na osnovi rezultata dobivenih iz zamrznutih uzoraka. Prikazani su sljedeći podaci bolesnica: dob, promjer tumora, tumorski biljezi i izvedeni operativni zahvati, u odnosu na literaturne podatke. Statistička analiza je provedena primjenom programa SPSS. Srednja dob bolesnica bila je 43,84 11,34 godine. Tumorska masa bila je smještena u desnoj (n=13) ili lijevoj $(n=11)$ adneksnoj regiji, a kod jedne bolesnice u objema adneksnim regijama. Srednji promjer tumora bio je $12,9 \pm 5,84$ $\mathrm{cm}$. Histopatološkom analizom postavljena je dijagnoza seroznog graničnog $(\mathrm{n}=14)$ i mucinoznog graničnog $(\mathrm{n}=11)$ tumora jajnika. Iako su rezultati ovoga istraživanja sukladni literaturnim podacima, potrebno je provesti veći broj studija graničnih tumora jajnika, koji se definiraju kao vrsta tumora različita od epitelnih tumora jajnika.

Ključne riječi: Ovarijski tumori - dijagnostika; Ovarijski tumori - klasifikacija; Cistadenokarcinom, serozni - dijagnostika; Karcinom, ovarijski epitelni - dijagnostika 